INTERNATIONAL JOURNAL OF ENVIRONMENT

Volume-6, Issue-1, Dec-Feb 2016/17

ISSN 2091-2854

Received: 4 March 2016

Revised: 17 Feb 2017

Accepted: 25 Feb 2017

\title{
ORGANIC CARBON STOCKS, DYNAMICS AND RESTORATION IN RELATION TO SOILS OF AGROECOSYSTEMS IN ETHIOPIA: A REVIEW
}

\author{
Getaneh Gebeyehu $^{1} *$, Teshome Soromessa ${ }^{2}$ and Demel Teketay ${ }^{3}$ \\ ${ }^{1,2}$ Center for Environmental Science, Addis Ababa University, P. O. Box 1176, Addis Ababa, Ethiopia \\ ${ }^{3}$ Botswana University of Agriculture and Natural Resources, Department of Crop Science and \\ Production, Private Bag 0027, Gaborone, Botswana \\ *Corresponding author: getanehgebeyehu@yahoo.com
}

\begin{abstract}
Soils represent the largest carbon pool and play important roles for carbon storage for prolonged periods in agroecosystems. A number of studies were conducted to quantify soil organic carbon (SOC) worldwide. The objective of this review was to evaluate organic carbon stocks, dynamics and restoration in soils of agroecosystems in Ethiopia. Soil data from 32 different observations, representing four different agroecosystems, were analysed. The mean SOC stocks in the four agroecosystems varied and ranged from 25.66 (sub-humid agroecosystem) to 113.17 (humid midhighland agroecosystems) $\mathrm{Mg} \mathrm{C} \mathrm{ha}^{-1}$ up to one meter depth. The trend of mean SOC followed (in descending order): humid mid-highland (113.17 $\left.\mathrm{Mg} \mathrm{C}^{-1}\right)>$ per-humid highland (57.14 $\left.\mathrm{Mg} \mathrm{C} \mathrm{ha}^{-1}\right)>$ semi-arid (25.77 $\left.\mathrm{Mg} \mathrm{C} \mathrm{ha}^{-1}\right)>$ sub-humid (25.66 $\mathrm{Mg} \mathrm{C} \mathrm{ha}^{-1}$ ). Compared with soils of tropical countries, those in Ethiopian agroecosystems contained low SOC storage potential. This might be associated with differences in measurement and analysis methods as $53.1 \%$ of the studies employed the Walkley-Black Method, which is known to underestimate carbon stocks in addition to ecological and management effects. However, shifts of land management from rain-fed to irrigation farming systems exhibited progress in the improvement of mean SOC storage potential. The analyses showed that farming systems involving irrigation sequestered more carbon than rain-fed farm systems. The mean SOC in the various agricultural land uses followed the following trend (in descending order): agroforestry (153.57 $\left.\mathrm{Mg} \mathrm{C} \mathrm{ha}{ }^{-1}\right)>$ grazing land (34.61 $\mathrm{Mg} \mathrm{C} \mathrm{ha}^{-1}$ ) > cereal cultivation (24.18 $\mathrm{Mg} \mathrm{C}^{-1}$ ). Therefore, the possible solutions for improvement of organic carbon stocks would be implementation of appropriate restoration strategies based on agroecosystems.
\end{abstract}

Keywords: Agricultural land uses, organic carbon stocks, organic carbon dynamics, soils of agroecosystems 


\section{Introduction}

Carbon (C) exists in the atmosphere in the form of carbon dioxide $\left(\mathrm{CO}_{2}\right)$ whereas it can be found in the soil as organic and inorganic forms. It is predicted that the concentration of $\mathrm{CO}_{2}$ has shown additional of $111 \mathrm{ppm}$ in the atmosphere during 1850 to 2012 (WMO, 2012; Andres et al., 2012). The major sources of rising $\mathrm{CO}_{2}$ concentration in the atmosphere are anthropogenic activities, such as fossil fuel consumption, clearing of forests for expansion of agricultural land and burning of forest biomass. Anthropogenic impacts contribute to approximately 32 billion metric tons of $\mathrm{CO}_{2}$ emission into the atmosphere each year, of which deforestation accounts $20 \%$ worldwide. This is estimated to be onethird of total greenhouse gas (GHG) emissions (IPCC, 2007). A total of 0.7 to $2.1 \mathrm{G} \mathrm{t} \mathrm{C} \mathrm{yr}^{-1}$ have been lost because of land use change and associated land use processes (World Bank, 2012).

Soil organic carbon can be defined as the content of carbon in soils as a result of decaying remains of living organisms such as plants, animals and microorganism in various stages. It represents a dynamic balance between the inputs and loss from decomposition. This dynamic nature shows variations of SOC distribution in spatial and temporal scales (Hobley and Willgoose, 2010). SOC stocks can also vary spatially in agricultural land use and ecosystem types (World Bank, 2012). The ways of estimation of soil carbon stocks and dynamics range from field to global levels (Hillier et al., 2011). Global soil atlas provides reliable set of soil data that could not be limited by geographical and measurement scale (Global Soil Mapping, 2011).

Soils represent the largest carbon pools in agroecosystems and have a potential for storage of carbon for prolonged periods. Many research methods were built up to quantify SOC worldwide. The most recent reports have shown that soils contain 2 - 2.5 times $(1500-2500 \mathrm{Gt})$ of carbon as does the atmosphere $(560 \mathrm{Gt})$ and four times larger as the biotic pool $(560 \mathrm{Gt})$ up to $1 \mathrm{~m}$ depth (Smith, 2004; Lal, 2004). At the global scale, soils of agroecosystems play vital roles on sequestration of about 2.1

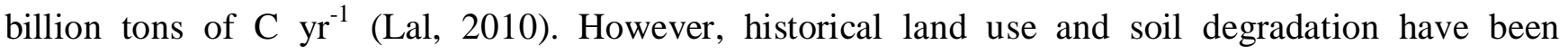
attributed for the loss of 25 to $75 \%$ of the original SOC from agroecosystems (croplands and grazing lands). It could be equivalent to the loss of more than 78 billion tons of carbon globally (Lal, 2004).

Estimations of African soils have shown that SOC stocks ranged from 133,420 - 184,116 Tg up to $1 \mathrm{~m}$ soil depth. The most recent quantification of SOC stocks in the continent has been estimated at 166,397 Tg C. This corresponds to $9 \%$ of global SOC stocks and $68 \%$ of the terrestrial C pool in Africa (Henry et al., 2009). Such amount of SOC varies in spatial scale between countries and regions. The highest SOC stocks are found in Middle Africa (33\%) and East Africa (26.6\%) regions while southern Africa contributes only $6 \%$ up to $1 \mathrm{~m}$ soil depth (Henry et al., 2009). At the country level, soils in Ethiopia contain 6,459 millions of tons of organic carbon up to $1 \mathrm{~m}$ depth (Henry et al., 2009), which corresponds to $13.9 \%$ of East African region and $3.9 \%$ of the African continent.

Soils, as structural element of agroecosystems, have potentials as carbon sources and sinks (Lal, 2007). Agroecosystems undertake carbon balancing in relatively short period (Han et al., 2008) because 
agricultural practices strongly affect carbon cycling between agroecosystems and the atmosphere than other terrestrial ecosystems (Sainju et al., 2008). Therefore, many scientific communities aspire to search for efficient restoration techniques and management strategies of agroecosystem to sequester atmospheric $\mathrm{CO}_{2}$. Management of agroecosystems is an important approach to restore SOC pools. SOC storage is a universal indicator to assess the status and improvement of land management and soil fertility (Lal, 2007; Patrick et al., 2013). It has been addressed through improvement of degraded agroecosystems, enhancement of organic carbon pool and assisting soil quality (Lal, 2011). Storage of SOC minimizes environmental problems, mitigates climate change and supports sequestration of more carbon in soils of agroecosystems (Lal, 2011).

Agroecosystems are very different from natural ecosystems because human activities manipulate soils, vegetation and other natural resources in the system for growing crops and other environmental benefits (Gliesman, 2007). These human activities can affect the nature of SOC stocks in spatial and temporal scale in agroecosystems than other ecosystems. Therefore, the purpose of focusing on agroecosystem was to analyze organic carbon storage, dynamics and restoration in relation to soils of agroecosystems in Ethiopia.

\section{Materials and Methods}

\section{Study areas}

Agroecosystems can be classified by agroecological factors, which determine classification of agroecological zones (Wood et al., 2000). Similarly, the present SOC data in agroecosystems were compiled refereeing to agroecological zones. Current agroecological zones in Ethiopia are classified as major categories of arid, semi-arid, sub-moist: moist, sub-humid, humid and peri-humid using temperature and moisture regimes (EIAR, 2011). Out of these categories, soil carbon stocks in semiarid, sub-humid, humid and peri-humid areas were the main data sources for this study (Table 1). The altitude of these areas ranged from 800 to $3200 \mathrm{~m}$. The data were obtained and compiled only for these areas due to limited studies related to carbon stocks in other areas.

Table 1: The agro-ecosystems studied and their characteristics

\begin{tabular}{llll}
\hline $\begin{array}{l}\text { Agroecosyst } \\
\text { em }\end{array}$ & Salient Characteristics* & $\begin{array}{l}\text { Altitudinal } \\
\text { range (m)* }\end{array}$ & $\begin{array}{l}\text { Soil } \\
\text { Type(s)** }\end{array}$ \\
\hline Semi-arid & $\begin{array}{l}\text { High temperatures }\left(26-34{ }^{0} \mathrm{C}\right) \text {, low precipitation } \\
(400-700 \mathrm{~mm}) \quad(\text { Aridity index range }=0.20-\end{array}$ & $500-1500$ & $\begin{array}{l}\text { Xerosols, } \\
\text { volcanic } \\
\text { origin } \\
\text { (Adosols) }\end{array}$ \\
& $\begin{array}{l}\text { 0.50), poorly developed soils and low biomass } \\
\text { production, and pastoral/crop cultivation common }\end{array}$ & \\
& $\begin{array}{l}\text { Temperature }\left(15-30{ }^{0} \mathrm{C}\right), \text { precipitation }(700- \\
\text { Sub-humid }\end{array}$ & $1500-2100$ & $\begin{array}{l}\text { Xerosols, } \\
\text { volcanic }\end{array}$ \\
\hline
\end{tabular}




$\begin{array}{ll}\text { Humid mid- } & \text { Temperature }\left(18-20{ }^{0} \mathrm{C}\right) \text {, precipitation }(900- \\ \text { highland } & 1,500 \mathrm{~mm},(\text { Aridity index range }=0.65-0.75), \\ & \begin{array}{l}\text { and cultivation of annual and/or perennial crops } \\ \text { common }\end{array}\end{array}$

Nitosols, Cambisols, Lithosols,

Per-humid Temperature $\left(14-18{ }^{0} \mathrm{C}\right)$, precipitation $(1500$ highland $2,000 \mathrm{~mm}$, (Aridity index range > 0.75), and suited for perennial crop cultivation and forests

Nitosols, Cambisols, Lithosols

$*=\mathrm{MOA}(2000) ;$ and $* *=\mathrm{FAO}(1984)$.

In the study area, 32 soil data focusing on SOC stocks in cereal cultivation, grazing land and agroforestry were evaluated. In grazing lands, which were dominated by livestock production, studies on soil carbon stocks in free (open) communal grazing lands were considered.

\section{Methods of determination of SOC}

SOC can be determined using direct and indirect methods. Carbon content in soil samples can be directly determined by measuring soil variables. The most direct SOC determination involves collecting soil samples in the field, and samples can be analyzed in the laboratory by combustion techniques (Pearson, 2007; Hairiah et al., 2010). This method includes wet and dry combustion and various types of infrared spectroscopy. However, wet combustion is the most dominant direct method of SOC determination (Walkley-Black Method) followed by dry combustion techniques, and a few studies used infrared spectroscopy techniques for in situ measurement.

Indirect determination of SOC changes over large areas worldwide includes stratified accounting with database, remote sensing and simulation models. These are increasingly important to fill gaps in the direct SOC determination method. Replication of soil samples can be used to describe changes in SOC under varying climatic condition, soil and management types. It reduces extra wastage of money and time to estimate $\mathrm{CO}_{2}$ emissions in large area under a wide range of biological, physical and agricultural management conditions.

\section{Data analyses}

Data were quantified as mean, range and median to describe spatial distribution of SOC stocks in different agroecosystems, agricultural land uses and farmland management. In some research findings, SOC data were found in the form of raw data, such as soil depth, organic carbon concentration and bulk density. So, in this case, SOC stocks were calculated as SOC stocks = D * \% C * BD, where SOC is soil organic carbon $\left(\mathrm{Mg} \mathrm{C} \mathrm{ha}^{-1}\right)$, D is depth of soil layer $(\mathrm{cm}), \% \mathrm{C}$ is percent of carbon concentration $(\mathrm{g}$ $\left.100 \mathrm{~g}^{-1}\right)$ and BD is bulk density of soils $\left(\mathrm{g} \mathrm{cm}^{-2}\right)$. 


\section{Results and Discussion}

\section{SOC measurement and determination}

The results revealed that a large range of soils (96.9\%) were measured using ground-based measurements and laboratory analyses, and only a few (3.1\%) were model-based monitoring of sites (Table 2; Appendix 1).

Table 2: Methods of soil carbon determination employed by the observations

\begin{tabular}{|c|c|c|}
\hline Methods* & Number of observations & Proportion (\%) \\
\hline Walkley-Black Method & 17 & 53.1 \\
\hline Dry combustion & 12 & 37.5 \\
\hline Dry combustion and Infra-red spectroscopy & 2 & 6.3 \\
\hline Modeling and Walkley-Black Method & 1 & 3.1 \\
\hline $\begin{array}{ll} & \text { Total }\end{array}$ & 32 & 100 \\
\hline
\end{tabular}

* = See Appendix 1 for details.

A number of ground-based surveys are conducted to quantify SOC stocks (Pearson et al., 2007; Hairiah et al., 2010). The purposes of these studies were to determine the ways of $\mathrm{CO}_{2}$ emission as well as identify and measure changing soil carbon stocks (Lal, 2004). Different methods and direct or indirect measurements and use of models were employed to quantify SOC stocks (Mäkipää et al., 2012). The use of these different methods and measurements are to increase precision and accuracy during quantification of SOC (Smith et al., 2010).

\section{Direct methods of determination}

The results showed that the majority of SOC contents were determined by using laboratory analyses methods ranging from the older Walkley-Black method $(53.1 \%)$ to the modern method of drycombustion elemental analyzer (43.8\%). The largest application of ground-based soil survey was conducted and analyzed in Walkley-Black Method since it is easy to handle many samples and useful for assessing change of SOC. The accuracy of methods used to quantify the change in carbon stocks could contribute to variations among different research results. Amare et al. (2013) explained that determination of SOC using the Walkley-Black Method showed variations between and within sampling sites.

Although traditional Walkley-Black method has become popular procedure for determination of SOC, it lacks repeated measurement and good levels of replication. It can also lead to underestimation of carbon stocks because of the incomplete oxidation in the laboratory analysis (Hobley and Willgoose, 2010; Venkanna et al., 2014). In addition, it contributes to negative environmental impact because of the discharging of toxic chemicals. As the cost for chemicals involved in the Walkley-Black method is 
very high, it leads to low efficiency in carbon stock determination. Therefore, this traditional method of laboratory analysis becomes challenging for its continuous application to estimate SOC. On the other hand, instrumental error of modern dry combustion auto-analyzers could be less than $0.1 \%$. Hence, laboratory analysis using appropriate procedures showed 1-2\% measurement error in dry combustion techniques (FAO, 2001). However, elemental combustion techniques have also some limitations in practical work for many samples and sequential assessment of SOC (Aynekulu et al., 2011; Batjes, 2011). Therefore, the use of infrared spectroscopy method can minimize those limitations associated with Walkley-Black method and dry combustion methods for estimation of SOC stocks (Vågen et al., 2013; Amare et al., 2013). It is, thus, worth noting that quantification of SOC using Walkley-Black method contributes to inaccuracy and low precision of SOC determination.

\section{Model-based measurement}

Model-based measurement in this study accounts for $3.1 \%$, indicating the need for more estimation of SOC stocks to fill gaps on direct determination. A model-based soil carbon monitoring system consists of a model of soil carbon and input data to the model, and results in the determination of soil carbon. The method has been accepted as the most promising method for the estimation of the stocks and changes of SOC (Aynekulu et al., 2011; Mäkipää et al., 2012). Model-based evaluation of soil carbon can involve many inputs, such as litter production of vegetation, temperature and moisture affecting the decomposition rate of organic matter in the soil, and soil texture as affecting stabilization of organic matter in the soil and controlling soil moisture conditions. In addition, whenever land-use change is an important factor affecting soil carbon, it is essential to account for the effects of land-use change on a model-based soil carbon monitoring system. Therefore, model-based method can involve many soil variables associated with their significant roles on soil carbon stocks.

\section{Soil organic carbon dynamics at the level of agroecosystems}

The descriptive analyses revealed that mean soil carbon stocks between agroecosystems varied (Table 3). Compared with carbon storage in soils of agroecosystems of other tropical regions (Batjes, 1999; FAO, 2001), Ethiopian agroecosystems exhibited low carbon storage capacities (Table 3).The majority of measurements and analysis of soil carbon stock were achieved through Walkley-Black Method, which could result in the underestimation of findings in addition to ecological elements, e.g. climate, physiography, soils types, vegetation and farming systems) and management practices. These ecological elements can determine turnover of carbon in agroecosystems. Therefore, ecological elements coupled with farm management (e.g. irrigation or rain-fed) and land use practices (e.g. agroforestry) contributed variations on the distribution of soil carbon content along the agroecosystems. Many investigators explained that biotic factors and management activities, such as irrigation production in watershed areas at the local condition (Haile et al, 2014; Shiferaw et al., 2015) and ecological elements, such as climate at the large scale, like tropical regions (FAO, 2001), play fundamental roles and affect carbon inputs into the soil and decomposition processes (Girmay and Singh, 2012). 
Table 3: SOC storage ( $\mathrm{Mg} \mathrm{C} \mathrm{ha-1})$ in different agroecosystems of Ethiopia in comparison with tropical regions ( $1 \mathrm{~m}$ depth)

\begin{tabular}{lccccc}
\hline Agroecosystems & $\begin{array}{c}\text { Number of } \\
\text { Observations } \\
(\%)^{*}\end{array}$ & $\begin{array}{c}\text { Range of } \\
\text { SOC Stock } \\
\text { (Ethiopia) }\end{array}$ & $\begin{array}{c}\text { Mean SOC } \\
\text { (Ethiopia) }\end{array}$ & $\begin{array}{c}\text { Range of } \\
\text { SOC stock } \\
\text { (Tropical } \\
\text { Regions)** }\end{array}$ & $\begin{array}{c}\text { Mean SOC } \\
\text { (Tropical } \\
\text { Regions)** }\end{array}$ \\
\hline Semi-arid & $6(19)$ & $20.3-40.4$ & 25.77 & $37.1-40.8$ & 38.95 \\
Sub-humid & $9(28)$ & $13-36.6$ & 25.66 & $64.4-68.2$ & 66.3 \\
Humid mid-highland & $14(44)$ & $23.6-256.3$ & 113.17 & $176.8-182.5$ & 179.65 \\
Per-humid highland & $3(9)$ & $18.7-124.74$ & 57.14 & $56-59$ & 57.5 \\
\hline
\end{tabular}

$*$ = See Appendix 1 for details; and ** = FAO (2001).

\section{Semi-arid agroecosystems}

The analyses revealed that the soils of semi-arid agroecosystem have low carbon fixation capacity, with a mean SOC storage of $25.77 \mathrm{Mg} \mathrm{C}^{-1}$ than other agroecosystems (Table 3). Other studies have also shown that soils of semi-arid agroecosystems maintained low SOC stocks (Shrestha and Stahl, 2008), and the rate of carbon sequestration is retained slowly in the semi-arid tropics $\left(0.1-0.2 \mathrm{t} \mathrm{of} \mathrm{C} \mathrm{ha}^{-1} \mathrm{yr}^{-1}\right)$ as a factor of climate (FAO, 2001; Lal, 2004).

Compared with carbon saturation levels of the soils in semi-arid tropics $\left(73.21 \mathrm{Mg} \mathrm{ha}^{-1}\right)$ up to $60 \mathrm{~cm}$ soil depth (Venkanna et al., 2014), there is a need for greater efforts to improve SOC levels in semiarid agroecosystems of Ethiopia. Application of irrigation farming would improve carbon sequestration. On the other hand, application of low-input value for improvement of organic carbon in agroecosystem (Emiru and Gebrekidan, 2013) and naturally consisting of sandy and infertile soils might contribute to low carbon content in the soil (Gui et al., 2010). In addition, wind erosion of soils and deterioration of vegetation cover attribute to the decline of SOC and susceptibility for land degradation (Wani et al., 2009) in semi-arid agroecosystems. Low carbon storage potentials in semiarid agroecosystems reflect more $\mathrm{CO}_{2}$ emission into the air than sequestration in the soil. Such factors can play significant role for depletion of SOC pool, reduction of biomass productivity and exacerbate global warming (Lal, 2004).

Semi-arid regions are generally characterized by high temperatures, low precipitation, poorly developed soils and low biomass production (Raiesi, 2012). For improvement of carbon sequestration in these conditions, adequate management practices should be implemented to improve potential of the SOC stocks (Sousa et al., 2012). Effective implementation may reduce climate effects while it increases carbon storage potentials in soils.

As a result of these effects, multiple management efforts are required for restoring degraded soils, including agroecological-based technologies. Enhancing nutrient recycling mechanisms and adopting 
water harvesting measures (World Bank, 2010) as well as maintenance and restoration of woody vegetation, mainly trees, as wind erosion break ameliorate the effects of and improve ecosystem services in the area. Practice of agroforestry systems on semi-arid agroecosystems are limited and have not played significant role in carbon storage. Similar studies have shown that agroforestry systems have not shown significant role for carbon sequestration potential in semi-arid than those on fertile humid sites (Srinivasaraoet al., 2013). Stressing on irrigation and intensive soil cropping may improve soil quality in semi-arid regions (Mulualem et al., 2015), because these practices can result in greater SOC contents.

\section{Sub-humid agroecosystems}

The SOC in the sub-humid agroecosystem varies from 13 to $36.6 \mathrm{Mg} \mathrm{C}^{-1}$ (Table 3). Andosol soil type and its subsequent conversion into low-input agricultural systems are responsible for the lowest amount of SOC stock (Solomon et al., 2002; Emiru and Gebrekidan, 2013). For example, within similar elevation and amount of rainfall, significance differences of SOC stocks were observed in the Andosols of Alaba (14.4 Mg C ha ${ }^{-1}$ ) and Vertisol of Debrezit area (33.9 $\mathrm{Mg} \mathrm{C} \mathrm{ha}^{-1}$ ). These complex interactions between low-input agricultural systems and soil types affected the SOC storage capacities of agroecosystems. In general, the major factor contributing to low carbon stocks in sub-humid tropics is poor productivity (Venkanna et al., 2014).

\section{Humid mid-highland agroecosystems}

The humid mid-highland agroecosystem stored more SOC, ranging from 23.6 to $256 \mathrm{Mg} \mathrm{C}^{-1}$ (Table 3 ). The presence of Nitosols and agroforestry practices in Gedeo area has led to, relatively, the highest amount of SOC stocks (256 $\mathrm{Mg} \mathrm{C} \mathrm{ha}^{-1}$ ) (Table 3). In addition, large amount of $\mathrm{CO}_{2}$ can be sequestered in this agroecosystems as a consequence of availability of moderate temperature and rainfall, the good management practices and soil types. Studies have also shown that SOC stocks can increase with elevation due to relatively higher moisture levels and lower temperatures at the higher elevations (Hoffmann et al., 2014). Lower temperatures can limit organic matter decomposition rates. These conditions lead to low $\mathrm{CO}_{2}$ emission from the soil and, thus, contribute to higher SOC accumulation/stocks. The balance between primary productivity and soil respiration can result in soil organic accumulation. Therefore, enhancement of primary productivity through agroforestry systems can improve carbon storage potentials in the soil. However, continuous cultivation based on rain-fed agriculture and improper addition of fertilizers for increasing crop yield contributed to low storage of carbon and cause wide range of variation in SOC within the same agroecosystem.

\section{Per-humid agroecosystems}

The SOC storage in per-humid area ranged from 18.7 to $124.74 \mathrm{Mg} \mathrm{C}^{-1}$ (Table 3). The high storage of SOC in this system was due to commencement of intercropping of trees in agricultural areas while continuous cultivation with rain-fed practices resulted in low SOC storage. Many studies demonstrated that the soils in the Ethiopian highlands have been degraded (Hurni et al., 2007), causing major 
environmental problems (Haile et al., 2014) due to the change in land use systems with the aim of expansion of agricultural land. Hence, conservation and restoration measures, including soil and water conservation, are being implemented in cultivated areas and exclosures (Aerts et al., 2009; Teketay et al., 2010) in grazing lands to restore degraded lands (Shiferaw et al., 2015). As a consequence of such condition, SOC can be improved on the degraded areas of agroecosystems.

\section{Dynamics of soil carbon storage in farm land management}

The total extent of rain-fed and irrigated farming in agroecosystems account about 2.6 and 0.12 billion ha, respectively (FAO, 2001), of which 0.65 billion ha of cultivated lands are found in the tropical zone. The cultivated area in Ethiopia is estimated at about 12 million ha of land. Out of the cultivated land, the potential areas for irrigation land are estimated at one-fourth (three million hectares) of the country. However, most of the fertility of soils in the agroecosystems are highly deteriorated, which could also contribute to loss of organic carbon (ATA, 2013). The spatial distribution of SOC stocks in irrigated and rain-fed farmland systems are discussed in the following sections.

\section{Irrigated farming system}

An irrigation system is one of the farmland management practices that can be used to increase soil organic matter content by increasing productivity and biomass (FAO, 2001). Irrigated farmland soils stored relatively more SOC than rain-fed farmland soils (Table 4). This reflects that better management of irrigated farm land results in positive impacts on SOC stocks than rain-fed farmland. Previous studies also suggested that efficient use of inputs on irrigated farmlands sequestered more $\mathrm{CO}_{2}$ than rain-fed farmlands (Girmay et al., 2008; Mulualem et al., 2015). Irrigated systems, particularly in the semi-arid regions, can contribute to a rapid increase in SOC, focusing on relevance of crop residues to the soils and growing nitrogen fixing plants. In some of the dominant rain-fed cropping systems, cereal cultivation exhibited reduced organic carbon stock compared with grazing lands and agroforestry systems. This indicates that shifting from rain-fed cropland to irrigation cropland management improves productivity and environmental condition of agroecosystems (Mulualem et al., 2015) since these practices can contribute towards greater contents of soil organic matter. Therefore, diversification of cropland management, particularly, on cultivated soils could provide an opportunity for climate adaptation.

\section{Rain-fed farming system}

The mean SOC stock in rainfed-farming systems showed lower value than irrigated farm systems (Table 4). This reflected that high degree of soil degradation resulted in low carbon stocks in rain-fed farmlands due to continuous cultivation, poor management and low external input. The role of rain-fed framing systems differ regionally where it supports to produce most crops for poor communities in developing countries like Ethiopia. However, climate change can affect rain-fed farming, particularly in semi-arid regions (World Bank, 2010), and contributed to low potential of $\mathrm{CO}_{2}$ sequestration. The implication of high dependency of communities on rain-fed farming has aggravated soil degradation 
and, hence, better management is urgently needed to reverse the process before the soils lose their ecosystem services.

Table 4: Soil organic carbon stocks $\left(\mathrm{Mg} \mathrm{C} \mathrm{ha}^{-1}\right)$ in farmland management systems

\begin{tabular}{lcccc}
\hline $\begin{array}{l}\text { Farm } \\
\text { management } \\
\text { system }\end{array}$ & $\begin{array}{c}\text { Number of observations } \\
(\boldsymbol{\%})\end{array}$ & Range & Median & Mean \\
\hline Rainfed farm & $18(81.82)$ & $13-94.9$ & 25.75 & 31.60 \\
Irrigation farm & $4(18.18)$ & $21.95-102$ & 28.5 & 45.23 \\
\hline
\end{tabular}

\section{Dynamics of soil carbon stocks in agricultural land use types}

The analyses confirmed that the trend of mean soil carbon storage in agricultural land use types was: agroforestry $\left(153.57 \mathrm{Mg} \mathrm{C} \mathrm{ha}^{-1}\right)>$ grazing land (34.61 $\left.\mathrm{Mg} \mathrm{C} \mathrm{ha}^{-1}\right)>$ cereal cultivation $\left(24.18 \mathrm{Mg} \mathrm{C}^{-}\right.$ ${ }^{1}$ ) up to $1 \mathrm{~m}$ depth (Table 5).

Table 5: Spatial distribution of SOC stocks in agricultural land use

\begin{tabular}{lcccc}
\hline Land use & Observations* & Range & $\begin{array}{c}\text { Mean SOC stock (Mg C } \\
\text { ha }^{-\mathbf{1}} \text { ) in Ethiopia }\end{array}$ & $\begin{array}{c}\text { Globally SOC stocks (Mg C } \\
\text { ha }^{-\mathbf{1}} \text { ) and references }\end{array}$ \\
\hline Agroforestry & 9 & $49.41-256.3$ & 153.57 & $30-300$ ( Nair et al., 2010) \\
Cereal cultivation & 20 & $36.6-102$ & 24.18 & 50 (Lal, 2004) \\
Grazing land & 3 & $22-41.03$ & 34.61 & 100 ( Silver et al., 2010) \\
\hline * See appendix for details. & & & &
\end{tabular}

Table 5 clearly indicates that agricultural land use influences SOC and implies that the values are minimal compared with organic carbon stocks across other land use types. SOC stocks can vary spatially across agricultural land use type (World Bank, 2012). Effects of agricultural land use could contribute to variations of SOC stocks in spatial scales of agroecosystems. For the analyses of agricultural land use, three main land use types were distinguished, of which crop cultivation was the dominant land use type.

\section{Soils of cereal cultivation}

SOC stock potential in cereal cultivation ranged from $13 \mathrm{Mg} \mathrm{C} \mathrm{ha}^{-1}$ in the sub-humid agroecosystems to $102 \mathrm{Mg} \mathrm{C} \mathrm{ha}^{-1}$ in humid mid-highland agroecosystems with a mean value of $24.18 \mathrm{Mg} \mathrm{C} \mathrm{ha}{ }^{-1}$. Lal (2004) stated that achievement of $50 \mathrm{Mg} \mathrm{C} \mathrm{ha}^{-1}$ stocks in soils of cropland is important for global conservative concerns and, thus, cropland management should be integrated for restoring degraded soil organic matter. The most prominent cereal cultivation includes maize, teff and barely in the studied 
sites. Low carbon input in the form of cereal crop residue, reduced tree cover and continuous cultivation resulted in the lowest stocking potentials while the largest carbon stocks potential was observed in farmlands with a combination of farm management systems, modest climatic condition and dominant soil types. Many studies also explained that land use influences SOC stocks (Mekuria et al., 2009; Gebremariam and Kebede, 2010; Abera and Belachew, 2011; Habtamu et al., 2014; Haile et al., 2014) and quality of the environment (Lal, 2004; Ndor and Ioruka, 2013).

A variety of local factors including climatic condition, soil properties as well as land use and management practice can contribute to the change of soil carbon stocks. Accordingly, lower amounts of organic carbon storage have been found in soils of cereal cultivation than other land use systems. Continues cultivation might contribute to the reduction of carbon storage in this land use. This suggests the need for sustainable cropping systems and management to improve soil carbon storage. Therefore, improvement of crop residues, reduce tillage operation, improvement of fertilizer application, choice of crop for carbon management and irrigation systems have a potential for improvement of soil fertility and restoration of degraded areas (Lal, 2004; Srinivasarao et al., 2013). Such land management can adjust soil carbon stocks to varying degrees (Lal, 2004; Singh et al., 2008; Srinivasarao et al., 2013).

\section{Soils of agroforestry systems}

Agroforestry is one of the land-use systems that involves growing of trees or other woody perennials on agricultural crops and pastures. The purpose of this land use system is to improve productivity of agricultural land and pastures, and utilize the ecological and economic interactions of different components (Srinivasarao et al., 2013). The agroforestry systems studied showed higher potential of carbon storage capacities in the soils of humid agroecosystems up to1m depth (36.6 - 256.3 $\mathrm{Mg} \mathrm{C} \mathrm{ha}^{-1}$ ). In particular, complex agroforestry systems, such as coffee, enset and enset-coffee agroforestry practices harbor high levels of carbon stocks. Similarly, Nair et al. (2010) found that carbon stored in

the soils range from 30 to $300 \mathrm{Mg} \mathrm{C}^{-1}$ up to $1 \mathrm{~m}$ depth in agroforestry systems which could be attributed as distinct feature of agroforestry practices from other forms of agriculture. Similar studies concluded that soils of agroforestry practices sequestered higher amounts of organic carbon (Haileslassie et al., 2006; Singh et al., 2010; Nair et al., 2010; Haile et al, 2014; Negash and Starr, 2015; Mulualem, et al., 2015) due to addition of organic matter with litter decomposition and management, including high organic matter inputs (Haileslassie et al., 2006) than cereal-based systems.

Agroforestry systems also provide opportunities for conservation of diverse biological species (Schroth et al., 2004; Richards and Mendez, 2014) due to inclusion of coffee, enset and other tree species into the agricultural landscapes. Agroforestry systems perform key roles in conservation of diverse biological species by providing supplementary habitat for species, reducing rates of conversion of natural habitat and creating networks between habitats and modified forest remnants. Agroforestrybased systems are among bio-farming systems that can be used by small holder farmers to minimize external inputs and, hence, are recommended to sustain agricultural production on slopy lands (Lin et 
al., 2011; Simane et al., 2013). This contributes to improve agro-ecosystems by reducing soil erosion, thereby, reducing losses of water and nutrients.

\section{Soils of grazing lands}

The grazing lands accumulated higher mean SOC than cereal cultivated lands, but they exhibited lower mean SOC than agroforestry practices (Table 5). Addition of organic input from cow dung may contribute to slight increment of organic matter in the grazing lands compared with cultivated lands (Mekuria et al., 2009; Haile et al., 2014; Mekuria et al., 2014), but overgrazing may cause degradation of soil organic matter compared with agroforestry systems (Haile et al., 2014). Many findings have shown that grasslands can fix organic carbon in the soil reaching up to $100 \mathrm{Mg} \mathrm{C} \mathrm{ha}^{-1}$ ) (Silver et al., 2010). For instance, conversion of free grazing lands to area exclosures have shown potential of increasing carbon stocks in the area (Mekuria et al., 2009), and if continued, this strategy may contribute to achieve equilibrium state in carbon sequestration.

\section{Effects of dominant soil types on carbon storage}

Soil types are important for crop production and storage of organic carbon. Soil organic stocks across soil types varied from $13 \mathrm{Mg} \mathrm{Cha}^{-1}$ in Andosols to $102 \mathrm{Mg} \mathrm{C} \mathrm{ha}^{-1}$ in Vertisols with similar agricultural land use (Table 5).

Table 6: Soil organic carbon stocks in dominant soil types

\begin{tabular}{|c|c|c|c|c|}
\hline Soil class * & Taxonomy * & $\begin{array}{l}\text { Sub-tropical dry to } \\
\text { sub-tropical moist } \\
\left(\mathrm{Mg} \mathrm{C} \mathrm{ha}^{-1}\right) * *\end{array}$ & Soil types** & $\begin{array}{l}\text { Range of carbon } \\
\text { stocks }\left(\mathrm{Mg} \mathrm{C} \mathrm{ha}^{-1}\right) \\
\text { in Ethiopia }\end{array}$ \\
\hline $\begin{array}{l}\text { High } \\
\text { activity } \\
\text { clay soils }\end{array}$ & $\begin{array}{l}\text { Vertisols, Mollisols, Inceptisols, } \\
\text { Aridisols and high base status } \\
\text { Alfisols }\end{array}$ & $42-57$ & $\begin{array}{l}\text { Lithosols } \\
\text { (Leptosols) } \\
\text { Cambisols }\end{array}$ & $\begin{array}{r}23.7-34.9 \\
25-49\end{array}$ \\
\hline $\begin{array}{l}\text { Low } \\
\text { activity } \\
\text { clay soils }\end{array}$ & $\begin{array}{l}\text { Ultisols, Oxisols, acidic Alfisols } \\
\text { and many Entisols }\end{array}$ & $39-47$ & Nitisols & 65.2 \\
\hline Sandy soils & $\begin{array}{l}\text { Any soils with greater than } 70 \% \\
\text { sand and less than } 8 \% \text { clay (often } \\
\text { Entisols) }\end{array}$ & $33-50$ & Andosols & $13-27$ \\
\hline
\end{tabular}

Dominant soil types are found from sub-humid to humid area of the country (FAO, 1984). Vertisols are responsible for the highest range of SOC stocks in the study sites. This is because of their relatively 
better fertility compared with the other major soils. Vertisols are dominant soil types in highland areas, specifically on flat or gentle slopes. Andosols are mainly found in semi-arid and sub-humid areas, particularly in low land areas (see Appendix 1).

According to IPCC (2006), soils can be classified into three main classes. Each class consists of different soil taxonomy (Table 6). Six dominant soil types, i.e. Vertisols, Cambisols, Nitosols, Regosols, Leptosols and Fluvisols, cover half of the land mass of Ethiopia and are important as arable soils (Hurni et al., 2007). Out of these, five dominant soil types (Vertisols, Lithosols, Cambisols, Nitosols and Andosols) that affect distribution of organic carbon stocks were found on four agroecosystems.

Nitosols dominantly occur from sub-moist to humid areas, and these soils are highly weathered, acidic, high phosphorus fixing and well drained. However, Nitosols are vulnerable to erosion and leaching. Cambisols occur in the steep slopes and spread all over the country, but, mainly, they border the large areas of Nitosols in the highlands. They show wider variability than the other major cultivated soils in the country. Lithosols are also found in the highlands.

Results of previous studies also showed that dominant soil types affected carbon stocks in the ecosystems (Itanna et al., 2011). However, agricultural land use and management practices aggravated the change of SOC stocks. It should be noted that improvement of land use and management of agroecosystems can promote better carbon sequestration.

\section{Restoration based on agroecosystems and land use types}

Agroecosystems provide a lens for adaptation that takes into account ecological element differentiation and farming systems (Simane et al., 2013). Restoration of soil organic pool and improvement in soil quality may become future solutions of climate change (Lal, 2004). Soil restoration depends on agroecosystem-based technologies. For instance, water harvesting structures for irrigation systems and vegetation cover have been shown to improve the SOC in semi-arid areas (Bateje, 1999). In addition, reclamation strategies become more effective in semi-arid areas that have been affected by salt during irrigation practices.

Restoration measures through management of livestock, improved species as well as fire and nutrient management would sustain grazing land condition, particularly, in semi-arid and sub-humid agroecosystems (Lal, 2004). Area exclosures are also passive restoration or rehabilitation strategy, particularly in grazing lands by reducing impacts from human activities, such as overgrazing and improve SOC stocks. Soil and water conservation is an important agroecosystem-based restoration strategy, particularly in humid areas. Cropland management could also be an important strategy in humid areas to enhance carbon sequestration through management of residues, proper tillage operations, and proper application of fertilizers and choice of crops having high carbon input, irrigation management and fallow systems (Lal, 2004). Moreover, intercropping systems of trees in the farmlands 
of humid ecosystems have been proven as potential means of restoration of SOC (Singh, et al. 2010). This restoration of ecosystems could improve carbon sequestration in a sustainable manner.

\section{Conclusions}

The study confirmed that trends of mean carbon storage in the different agroecosystems in Ethiopia represent the following order: humid mid-highland > per humid highland > sub-humid > semi-arid. Comparatively, SOC stocks in these areas have shown lower amounts than in other tropical regions. This might have resulted from effects of land use, management and soil types. Soil types, agricultural land use and management practices play important role for spatial variation of organic carbon stocks in the soils of agroecosystems. The analyses also revealed that dominant soil types have greater mean carbon storage capacities than others. Agricultural land use types also contributed to the variations of organic carbon storage in the soil. SOC stocks are higher in agroforestry systems followed by areas with cereal and grazing lands. Therefore, agroforestry practices are the best strategies to increase sequestration of organic carbon, particularly in sub-humid and per-humid areas. Farmland management using irrigation system is also a promising strategy to improve SOC stocks. The study also showed that soil and water conservation in per-humid areas, exclosures in grazing lands and management of cereal cultivation are the best strategies for the restoration of soil carbon pools in agroecosystems. Therefore, it is recommended that possible solutions for improvement of organic carbon stocks would be the implementation of appropriate restoration strategies in agroecosystems.

\section{Acknowledgements}

All researchers whose research articles were used in the preparation of this review paper are gratefully acknowledged. Finally, we are thankful to the two anonymous reviewers for their valuable comments on an earlier version of the manuscript.

\section{References}

Abera, G. and Wolde-Meskel, E., 2013. Soil properties, and soil organic carbon stocks of tropical Andosol under different land uses. Open Journal of Soil Science, 3, 153-162.

Abera,Y. and Belachew, T., 2011. Effects of land use on soil organic carbon and nitrogen in soils of bale, southeastern Ethiopia. Tropical and Subtropical Agroecosystems, 14, 229- 235.

Aerts, R., Nyssen, J., Haile, M., 2009. On the difference between exclosures and enclosures in ecology and the environment. Journal of Arid Environments, 73, 762-763.

Agricultural Transformation Agency (ATA), 2013. Status of soil resources in Ethiopia and priorities for sustainable management. In: Proceedings of the Global Soil Partnership (GSP) for Eastern and Southern Africa Launching Workshop, Nairobi, 25-27. 
Amare, T., Hergarten, C., Hurni, H., Wolfgramm, B., Yitaferu, B. and Gebere Selassie, Y., 2013. Prediction of soil organic carbon for Ethiopian highlands using soil spectroscopy. ISRN Soil Science, 1-12.

Andres, R.J., T.A. Boden, and G. Marland, 2012. Monthly fossil-fuel $\mathrm{CO}_{2}$ emissions: mass of emissions gridded by one degree latitude by one degree longitude. Carbon Dioxide Information Analysis Center (CDIAC), Oak Ridge National Laboratory, U.S. Department of Energy, Oak Ridge, Tenn., U.S.A. doi: 10.3334/CDIAC/ffe. Monthly Mass.

Aynekulu, E., Vagen,T.G., Shephard, K. and Winowiecki, L. , 2011. A protocol for modeling, measurement and monitoring soil carbon stocks in agricultural landscapes. Version 1.1. World Agroforestry Centre, Nairobi.

Batjes, N.H., 2011. Research needs for monitoring, reporting and verifying soil carbon benefits in sustainable land management and GHG mitigation project. In: Monitoring, reporting and verification systems for carbon in soils and vegetation in African, Caribbean and Pacific Countries (De Brogniez D., Montaraella L.,eds). European Commission Joint Research Center, Brussels, 27-39.

Batjes, N.H., 1999. Management Options to for reducing $\mathrm{CO}_{2}$ concentrations in the atmosphere by increasing carbon sequestration in the soil. Report 410-200-031, Dutch national research program on Global air pollution and climate and technical report 30, International soil reference and information Centre, Wageningen, p. 15-18.

Emiru, N, and Gebrekidan, H., 2013. Effect of land use changes and soil depth on soil organic matter, total nitrogen and available phosphorus contents of soils in Senbat Watershed, Western Ethiopia. ARPN Journal of Agricultural and Biological Science, 8 (3), 206-212.

Ethiopian Institute of Agricultural Research (EIAR), 2011. Coordination of national agricultural research system, Ethiopia. English Version. EIAR, Addis Ababa, p. 120.

FAO, 2001. Soil carbon sequestration for improved land management. World soil resources reports. Food and Agriculture Organization of the United Nations, Rome.

FAO, 1984. Geomorphology and Soils. Assistance to land use planning project, Ethiopia. Field document 2, AG: DP/ETH/781003, Addis Ababa, Ethiopia, p. 1-238.

Gebremariam, M. and Kebede, F., 2010. Land use change effect on soil carbon stock, above ground biomass, aggregate stability and soil crust: A Case from Tahtay Adyabo, North Western Tigray,Northern Ethiopia. Journal of the Drylands, 3(2), 220-225. 
Gedefaw, M. and Bekele, M., 2014.Changes in carbon stocks and sequestration potential under Native Forest and Adjacent Land use Systems at Gera, Southwestern Ethiopia. Global Journal of Science Frontier Research: D Agriculture and Veterinary, 14 (10), 1-11.

Girmay, G. and Singh, B. R., 2012. Changes in soil organic carbon stocks and soil quality: land-use system effects in northern Ethiopia, Acta Agriculturae Scandinavica, and Section B - Soil and Plant Science, 62(6), 519-530.

Girmay, G., Singh, B. R., Mitiku, H., Borresen, T. and La, R., 2008. Carbon stocks in Ethiopian soils in relation to land use and soil management. Land Degrad. Develop., 19, 351-367.

Gliesman, S.R, 2007. Agroecology: The ecology of sustainable food systems, $2^{\text {nd }}$ ed. CRC press, Taylor and Francis Group, New York., p., 23-32.

Global Soil Mapping, 2011. Global Soil Information Facilities, http://www.globalsoilmap.net/category/ image-galleries/global-soil-information facilities-book, (Accessed on November 23, 2016).

Gui, D.W., Lei, J.Q. and Zeng, F.J., 2010. Farmland management effects on the quality of surface soil during oasification in the southern rim of the Tarim Basin in Xinjiang, China. Plant Soil Environ., 56, 348-356.

Habtamu, A., Heluf, G., Bobe, B. and Enyew, A., 2014. Fertility status of soils under different land uses at Wujiraba Watershed, North-Western Highlands of Ethiopia. Agriculture, Forestry and Fisheries, 3(5), 410-419.

Haile, G., Lemenhi, M., Itanna, F. and Senbeta, F., 2014. Impacts of land use changes on soil fertility, carbon and nitrogen stock under smallholder farmers in Central Highlands of Ethiopia: Implication for sustainable agricultural landscape management around Butajira Area. N Y Sci J, 7(2), 27-44.

Haileslassie, A., Priess, J. A., Veldkamp, E. and Lesschenm, J. P., 2006. Smallholders' soil fertility management in the Central Highlands of Ethiopia: implications for nutrient stocks, balances and sustainability of Agroecosystems. Nutr. Cycl. Agroecosyst., 75, 135-146.

Hairiah, K., Dewi, S., Agus, F., Velarde, S., Ekadinata, A., Rahayu, S. and Van Noordwijk, M., 2010. Measuring carbon stocks across land use systems: A Manual. World Agroforestry Centre (ICRAF), Bogor, p. 82-94.

Han, G. X., Zhou, G. S. and Xu, Z. Z., 2008. Research and prospects for soil respiration of farmland ecosystems in China. Journal of Plant Ecology, 32 (3), 719-733.

Henry, M., Valentini, R., and Bernoux, M., 2009. Soil carbon stocks in ecoregions of Africa. Biogeosciences Discuss, 6, 797-823. 
Hillier, J., Walter, C., Malin, D., Garcia-Suarez, T., Mila-i-Canals, L. and Smith, P., 2011. A farmfocused calculator for emissions from crop and livestock production. Environmental Modelling and Software, 26, 1070-1078.

Hobley, E. and Willgoose, G., 2010. Measuring soil organic carbon stocks - issues and considerations.19th World Congress of Soil Science, Soil Solutions for a Changing World Brisbane, Australia, p. 1-6.

Hoffmann, U., Hoffmann, T., Johnson, E.A. and Kuhn, N.J., 2014. Assessment of variability and uncertainty of soil organic carbon in a mountainous boreal forest (Canadian Rocky Mountains, Alberta). Catena, 113, $107-112$.

Hurni, H., Bantider, A., Herweg, K., Portner, B and Veit, H., 2007. Landscape transformation and sustainable development in Ethiopia. Background information for a study tour through Ethiopia, CDE (Center for Development and Environment), University of Bern, Bern, p.321.

IPCC, 2007.Climate change 2007: mitigation of climate change. Working Group IIIto the Fourth Assessment Report of the Intergovernmental Panel on Climate Change [B. Metz, O.R. Davidson, P.R. Bosch, R. Dave, L.A. Meyer (eds)], Cambridge, UK: Cambridge University Press, p. 3-12.

Itanna, F., Olsson, M. and Stahr, K., 2011. Effect of Land Use Changes on Soil Carbon Status of Some Soil Types in the Ethiopian Rift Valley. Journal of the Drylands, 4(1), 289-299.

Lal, R., 2004. Soil carbon sequestration impacts on global climate change and food security. Science, 304, 1623-1627.

Lal, R., 2007. Residue management, conservation tillage and soil restoration for mitigating greenhouse effect by $\mathrm{CO}_{2}$-enrichment.Soil Tillage Res., 43, 81-107.

Lal, R., 2010. Managing soils and ecosystems for mitigating anthropogenic carbon emissions and advancing global food security. BioScience, 60, 708-721.

Lal, R., 2011. Sequestering carbon in soils of agro-ecosystems. Food Policy, 36, S33-S39.

Mäkipää, R., Liski, J., Guendehou, S.,Malimbwi, R. and Kaaya, A., 2012. Soil carbon monitoring using surveys and modeling. General description and application in the United Republic of Tanzania. FAO, Rome, p. 1-18.

Mekuria, W., Veldkamp, E. and Haile, M., 2009. Carbon stock changes with relation to land use conversion in the lowlands of Tigray, Ethiopia. Conference on International Research on Food Security, Natural Resource Management and Rural Development, Tropentag, p. 1-6. 
Mekuria, W., Langan, S., Noble, A. and Johnston, R., 2014. Soil Organic Carbon and Nutrient Contents are not influenced by Enclosures Established in Communal Grazing Land in Nile Basin, Northern Ethiopia. International Conference on Advances in Agricultural, Biological \& Environmental Sciences (AABES-2014), Oct 15-16, Dubai (UAE).

Mulualem A.G., Singh, B. R. and Lal, R., 2015. Soil Quality Indices for Evaluating Smallholder Agricultural Land Uses in Northern Ethiopia.Sustainability, 7, 2322-2337.

Nair, P.K.R, Nair, V.D, Kumar, B.M. and Showalter, J.M., 2010. Carbon sequestration in agroforestry systems. Advances in Agronomy, 108, 237-307.

Ndor, E. and Iorkua, S.A, 2013. Effect of agricultural land use on carbon sequestration and chemical properties of soil in Lafia, Southern Guinea Savanna Agroecosystems, Nigeria. Global Journal of Biodiversity Science and Management, 3(1), 68-72.

Negash, M. and Starr, M., 2015. Biomass and soil carbon stocks of indigenous agroforestry systems on the south-eastern Rift Valley escarpment, Ethiopia. Plant Soil, Springer International Publishing Switzerland, p. 1-15.

Patrick, M., Tenywa, J.S., Ebanyat, P., Tenywa, M.K., Mubiru, D.N., Basamba, T.A. and Leip, A., 2013. Soil organic carbon thresholds and nitrogen management in tropical Agroecosystems: concepts and prospects. Journal of Sustainable Development, 6 (12), 31-43.

Pearson, T. R.H., Brown, S. L. and Birdsey, R. A., 2007. Measurement guidelines for the sequestration offorest carbon. United States Department of Agriculture (USDA) Forest Service, Washington, D.C, p. 27-30.

Raiesi, F., 2012.Soil properties and C dynamics in abandoned and cultivated farmlands in a semi-arid ecosystem. Plant and Soil, 351, 161-175.

Richards, M. and Mendez, V.E. (2014).Interactions between carbon sequestration and shade tree species diversity in a smallholder coffee cooperative of El Salvador. Society for Conservation Biology, 28(2), 489-497.

Sainju, U. M, Jabro, J. D. and Stevens, W. B., 2008. Soil carbon dioxide emission and carbon content as affected by irrigation, tillage, cropping system and nitrogen fertilization. Journal of Environmental Quality, 37, 98-106.

Schroth, G., da Fonseca, G. A. B., Harvey, C. A., Gascon, C., Vasconcelos, H. L. and Izac, A., 2004. Agroforestry and biodiversity conservation into tropical landscapes. Washington DC: Island Press, p. 7-10. 
Shiferaw, A., Hergarten, C., Kaswamar ,T. and Zelek, G., 2015. Meta analysis of long -term land management effect on soil organic carbon in Ethiopia. Int. J. Agric. Res., 10 (1), 1-13.

Shrestha, G. and Stahl, P.D., 2008. Carbon accumulation and storage in semi-arid sagebrush steppe: effects of long-term grazing exclusion. Agriculture Ecosystems \& Environment, 125,173-181.

Silver, W.L., Ryals, R. and Eviner, V., 2010. Soil carbon pools in California's annual grassland ecosystems. Rangeland Ecology and Management, 63, 128-136.

Simane, B., Benjamin, F. Z. and Ozdogan, M., 2013.Agroecosystem Analysis of the Choke Mountain Watersheds, Ethiopia. Sustainability, 5, 592-616.

Singh, B.R, Girmay,G., Mitiku, H., Borresen, T. and Lal, R., 2008. Carbon stocks in Ethiopian soils in relation to land use and soil management. Land Degrad. Develop. John Wiley \& Sons, Ltd, 19, $351-367$.

Singh, R.B., Ambachew, A., Wele, D. A and Lal R., 2010. Soil carbon sequestration under chronosequences of agroforestry and agricultural lands in Southern Ethiopia.19th World Congress of Soil Science, Soil Solutions for a Changing World 1 - 6 August, Brisbane, Australia.

Smith, P., 2004. Carbon sequestration in croplands: the potential in Europe and the global context. European Journal of Agronomy, 20, 229-236.

Smith, P., Lanigan, G., Kutsch, W. L., Buchmann, N., Eugster, W., Aubinet, M., Ceschia, E., Béziat, P., Yeluripati, J. B., Osborne, B., Moors, E. J., Brut, A., Wattenbach, M., Saunders, M., and Jones, M. , 2010. Measurements necessary for assessing the net ecosystem carbon budget of croplands. Agric. Ecosyst. Environ., 139, 302-315.

Solomon, D., Fritzsche, F., Lehmann, J., Tekalign, M. and Zech, W., 2002. Soil Organic Matter Dynamics in the Sub-humid Agroecosystems of the Ethiopian Highlands: Evidence from Natural C Abundance and Particle-Size Fractionation. Soil Sci. Soc. Am. J., 66, 969-978.

Sousa. F.P, Ferreira, T.O, Mendonça, E.S, Romero, R.E and Oliveira, J.G.B., 2012. Carbon and nitrogen in degraded Brazilian semi-arid soils undergoing desertification. Agriculture, Ecosystems \&Environment, 148, 11-21.

Srinivasarao, Ch., Prasad, J.V.N.S., Naresh, K,. Naga Jyothi, Ch., SangeetaLenka,.Lenka, N. K., Purakayastha, T.J., Pathak, H., Ganeshamurthy, A.N., Singh R., Arunachalam A., SubbaRao, A., Gangwar, B., Venkateswarlu, B. and Sikka, A.K, 2013. Assessment of carbon sequestration in agriculture and agroforestry systems, NICRA Manual series 3.Central Research Institute for Dry land Agriculture, Hyderabad, Andhra Pradesh. 
Teketay, D., Lemenih, M., Bekele, T., Yemshaw, Y., Feleke, S., Tadesse, W., Moges, Y., Hunde, T., Nigussie, D., 2010. Forest Resources and Challenges of Sustainable Forest Management and Conservation in Ethiopia. In: Degraded Forests in Eastern Africa: Management and Restoration (Bongers, F., Tennigkeit, T., Eds.). Earthscan, London, United Kingdom, pp. 19-63.

Vågen, Tor-G., Leigh, A., Winowiecki, Abegaz, A., Kiros M. H., 2013. Landsat-based approaches for mapping of land degradation prevalence and soil functional properties in Ethiopia. Remote Sensing of Environment, 134, 266-275.

Venkanna, K., Mandal, U. K., Solomon, A. J., Raju, K. L., Sharma, Adake, R. V., Pushpanjali1,B. S., Reddy Rahul, N., Masane ,K., Venkatravamma and PedaBabu, B., 2014. Carbon stocks in major soil types andland-use systems in semiarid tropical region of southern India. Research Communications, Current Science, 106(4), 25.

Wani, S.P., Sreedevi, T.K., Rockström, J. and Ramakrishna, Y.S., 2009. Rainfed Agriculture: Unlocking the Potential (Wani, et al., S.P., eds). CAB International.

Wood, S., Sebastian, K.L., Scherr, S.J., 2000. Pilot analysis of global ecosystems: agroecosystems. World Resources Institute, Washington, D.C, p. 17-30.

WMO, 2012. World Metcorological Organization Greenhouse Gas Bulletin. Geneva. P.4.

World Bank, 2012. Carbon sequestration in agricultural soils. Washington, DC. World Bank, p. 5-17.

World Bank, 2010. Improving water management in rainfed agriculture: issues and options in water constrained production systems, The World Bank, p. 10-15. 


\section{Appendix 1: Organic carbon stocks in agricultural land uses, farming management systems and dominant soil types in four}

agroecosystems in Ethiopia.

\begin{tabular}{|c|c|c|c|c|c|c|c|c|c|c|c|c|}
\hline $\begin{array}{l}\text { Agricultural } \\
\text { land use }\end{array}$ & $\begin{array}{l}\text { Farm } \\
\text { Manage } \\
\text { ment } \\
\text { system }\end{array}$ & $\begin{array}{c}\text { SOC } \\
\text { stocks } \\
\left(\mathrm{MgC} \mathrm{ha}^{-1}\right)\end{array}$ & $\begin{array}{l}\text { Proportion } \\
\text { (\%) organic } \\
\text { carbon }\end{array}$ & $\begin{array}{c}\text { SOM } \\
(\%)\end{array}$ & $\begin{array}{l}\text { Depth } \\
\text { (cm) }\end{array}$ & $\begin{array}{l}\text { Methods } \\
*\end{array}$ & $\begin{array}{l}\text { Dominant Soil } \\
\text { types }\end{array}$ & $\begin{array}{l}\text { Altitude } \\
(\mathbf{m})\end{array}$ & $\begin{array}{c}\text { Temperature and } \\
\text { rainfall } \\
\left(\text { meanyr }^{-1}\right)\end{array}$ & $\begin{array}{l}\text { Agro-Ecological } \\
\text { Zone }\end{array}$ & $\begin{array}{ll}\text { Location } & \text { of } \\
\text { sample site } & \end{array}$ & References \\
\hline $\begin{array}{l}\text { Cereal } \\
\text { cultivation }\end{array}$ & Rain-fed & 65.2 & - & - & 30 & \multirow[t]{2}{*}{ WB } & \multirow[t]{2}{*}{$\begin{array}{l}\text { Arcisol, Nitisol } \\
\text { and Leptosol }\end{array}$} & \multirow[t]{2}{*}{$1890-2100$} & \multirow{2}{*}{$\begin{array}{c}1 \\
4.2^{\circ} \mathrm{C}-24.2^{\circ} \mathrm{C} \text { and } \\
1800-2000 \mathrm{~mm}\end{array}$} & \multirow[t]{2}{*}{$\begin{array}{l}\text { Humid } \\
\text { Highland }\end{array}$} & \multirow[t]{2}{*}{$\begin{array}{l}\text { Adjacent to Gera } \\
\text { forest }\end{array}$} & \multirow[t]{2}{*}{$\begin{array}{l}\text { Gedefaw and } \\
\text { Bekele (2014). }\end{array}$} \\
\hline $\begin{array}{l}\text { Coffee-based } \\
\text { cultivation }\end{array}$ & Rain-fed & 94.9 & - & - & 30 & & & & & & & \\
\hline $\begin{array}{l}\text { Cereal } \\
\text { cultivation }\end{array}$ & Irrigation & 28 & 1.2 & 2.04 & 80 & WO & $\begin{array}{l}\text { Vertisols, } \\
\text { Cambisols, } \\
\text { Regosols } \\
\text { and Fluvisols }\end{array}$ & $2300-2830$ & $8-15^{\circ} \mathrm{C}$ & Humid highland & Maileba & \multirow[t]{2}{*}{$\begin{array}{l}\text { Girmay and } \\
\text { Singh (2012) }\end{array}$} \\
\hline $\begin{array}{l}\text { Cereal } \\
\text { cultivation }\end{array}$ & Irrigation & 79 & 1.0 & 1.7 & 80 & WB & $\begin{array}{l}\text { Cambisol, } \\
\text { Leptosols and } \\
\text { Vertisols, }\end{array}$ & $2100-2160$ & $\begin{array}{c}20-30{ }^{\circ} \mathrm{C} \\
400-700 \mathrm{~mm}\end{array}$ & $\begin{array}{l}\text { Humid } \\
\text { highland }\end{array}$ & Guma Selassa & \\
\hline $\begin{array}{l}\text { Enset } \\
\text { cultivation }\end{array}$ & Rain-fed & 49.41 & 3.09 & 5.3 & 15 & WB & \multirow[t]{3}{*}{ Cambisols } & \multirow[t]{3}{*}{2100} & \multirow[t]{3}{*}{$\begin{array}{c}27.7^{\circ} \mathrm{C} \text { and } \\
6.5^{\circ} \mathrm{C} \text { and } 1058 \mathrm{~mm}\end{array}$} & \multirow{3}{*}{$\begin{array}{l}\text { Humid } \\
\text { mid highland }\end{array}$} & \multirow{3}{*}{ Meskan } & \multirow{3}{*}{$\begin{array}{l}\text { Haile et al. } \\
(2014)\end{array}$} \\
\hline $\begin{array}{l}\text { Cereal } \\
\text { cultivation }\end{array}$ & Rain-fed & 27.58 & 1.50 & 2.55 & 15 & WB & & & & & & \\
\hline Grazing land & Rain-fed & 41.03 & 2.31 & 3.9 & 15 & WB & & & & & & \\
\hline $\begin{array}{l}\text { Cereal } \\
\text { Cultivation }\end{array}$ & Irrigation & 25.19 & 1.65 & 2.82 & 100 & MW & - & $1923-2300$ & - & $\begin{array}{l}\text { Humid mid } \\
\text { highland }\end{array}$ & Gumara & \\
\hline $\begin{array}{l}\text { Cereal } \\
\text { cultivation }\end{array}$ & Rain-fed & 13 & 1.6 & 2.72 & 30 & $\overline{\mathrm{DCA}}$ & Andosol & $1643-1950$ & $9.4^{\circ} \mathrm{C}$ and $952 \mathrm{~mm}$ & Sub-humid & Awassa & \multirow{2}{*}{$\begin{array}{l}\text { Abera and } \\
\text { Belachew } \\
(2013)\end{array}$} \\
\hline $\begin{array}{l}\text { Cereal } \\
\text { cultivation }\end{array}$ & Rain-fed & 27 & 2.8 & 4.9 & 30 & DCA & Andosol & $1643-1950$ & $24^{\circ} \mathrm{C}$ and $650 \mathrm{~mm}$ & Semi-arid & Ziwaye & \\
\hline $\begin{array}{l}\text { Cereal } \\
\text { cultivation }\end{array}$ & Rain-fed & 22.65 & 1.28 & 2.28 & 50 & WO & $\begin{array}{ll}\text { Sandy } & \text { and } \\
\text { infertile } & \end{array}$ & $800-1500$ & $28.5^{\circ} \mathrm{C}$ & Semi arid & \multirow[t]{2}{*}{ TahtayAdyabo } & \multirow{2}{*}{$\begin{array}{l}\text { Gebremariam } \\
\text { and Kebede } \\
(2010)\end{array}$} \\
\hline Grazing land & Rain-fed & 22.41 & 1.60 & 2.72 & 50 & WO & $\begin{array}{ll}\begin{array}{l}\text { Sandy } \\
\text { infertile }\end{array} & \text { and } \\
\end{array}$ & $800-1500$ & $28.5^{\circ} \mathrm{C}$ & Semi arid & & \\
\hline $\begin{array}{l}\text { Cereal } \\
\text { cultivation }\end{array}$ & Rain-fed & 14.4 & 8 & 14.24 & 20 & \multirow[t]{2}{*}{$\begin{array}{l}\text { DC-LC- } \\
2000 \mathrm{~A}\end{array}$} & Vitric Andosol & 1920 & $700-1000 \mathrm{~mm}$ & Sub-humid & Alaba & \multirow{2}{*}{$\begin{array}{l}\text { Itanna et al. } \\
(2011)\end{array}$} \\
\hline $\begin{array}{l}\text { Cereal } \\
\text { cultivation }\end{array}$ & Rain-fed & 18.9 & 7 & 12.46 & 20 & & HaplicNitisol & 1620 & - & Sub-humid & Humbo & \\
\hline
\end{tabular}




\begin{tabular}{|c|c|c|c|c|c|c|c|c|c|c|c|c|}
\hline $\begin{array}{l}\text { Cereal } \\
\text { cultivation }\end{array}$ & Rain-fed & 20.3 & 9 & 16.02 & 20 & & CalcaricFluvisol & 1600 & $400-700 \mathrm{~mm}$ & Semi-arid & Ziway & \\
\hline $\begin{array}{l}\text { Cereal } \\
\text { cultivation }\end{array}$ & Rain-fed & 21.9 & 9.7 & 17.3 & 20 & & HaplicSolonetz & 1600 & $400-700 \mathrm{~mm}$ & Semi-arid & Bulbula & \\
\hline $\begin{array}{l}\text { Cereal } \\
\text { cultivation }\end{array}$ & Rain-fed & 33.9 & 14 & 24.92 & 20 & & $\begin{array}{l}\text { Pelli- } \\
\text { Eutric Vertisol }\end{array}$ & 1850 & $700-1000 \mathrm{~mm}$ & Sub-humid & DebreZeit & \\
\hline Agroforestry & Rain-fed & 174 & - & - & 100 & WB & AndicPaleudalf & $2137-2215$ & - & $\begin{array}{l}\text { Humid mid- } \\
\text { highland }\end{array}$ & Gambo District & \multirow{2}{*}{$\begin{array}{l}\text { Singh et al. } \\
(2010)\end{array}$} \\
\hline Agroforestry & Rain-fed & 159 & - & - & 100 & WB & AndicPaleudalf & $2137-2215$ & $\begin{array}{c}26.6^{\circ} \mathrm{C} \text { and } 10.4^{\circ} \mathrm{C} \\
973 \mathrm{~mm}\end{array}$ & $\begin{array}{l}\text { Humid mid- } \\
\text { highland }\end{array}$ & Gambo District & \\
\hline $\begin{array}{l}\text { Enset } \\
\text { Agroforestry }\end{array}$ & Rain-fed & 232 & - & - & 60 & WB & Nitisols & $2100-2400$ & - & $\begin{array}{l}\text { Humid mid- } \\
\text { highland }\end{array}$ & Gedeo & \multirow[t]{3}{*}{$\begin{array}{l}\text { Negash and } \\
\text { Starr (2015) }\end{array}$} \\
\hline Agroforestry & Rain-fed & 255.2 & - & - & 60 & WB & Nitisols & $1900-2200$ & - & $\begin{array}{l}\text { Humid mid- } \\
\text { highland }\end{array}$ & Gedeo & \\
\hline $\begin{array}{l}\text { Fruit and } \\
\text { coffee }\end{array}$ & Rain-fed & 256.3 & - & - & 60 & WB & Nitisols & $1500-1900$ & - & Sub-humid & Gedeo & \\
\hline $\begin{array}{l}\text { Cereal } \\
\text { (maize) } \\
\text { cultivation }\end{array}$ & Rain-fed & 26.3 & - & - & 10 & DCEA & $\begin{array}{l}\text { PlinthaquicPaleu } \\
\text { dalf }\end{array}$ & 1900 & $18^{\circ} \mathrm{C}$ & Sub-humid & Wushwush & \multirow[t]{2}{*}{$\begin{array}{l}\text { Solomon } \\
\text { et al. (2002) }\end{array}$} \\
\hline $\begin{array}{l}\text { Cereal } \\
\text { (maize) } \\
\text { cultivation }\end{array}$ & Rain-fed & 23.6 & - & - & 10 & DCEA & $\begin{array}{l}\text { TypicPalehumult } \\
\mathrm{s}\end{array}$ & 2100 & $\begin{array}{l}19^{\circ} \mathrm{C} \text { and } \\
1250 \mathrm{~mm}\end{array}$ & $\begin{array}{l}\text { Humid mid- } \\
\text { highland }\end{array}$ & $\begin{array}{l}\text { Munessa- } \\
\text { Shashemene }\end{array}$ & \\
\hline $\begin{array}{l}\text { Enset-system } \\
\text { cultivation }\end{array}$ & Irrigation & 124.74 & 4.2 & 7.14 & 30 & WB & Luvisols & $2880-3095$ & - & Humid highland & $\begin{array}{l}\text { Galesa } \\
\text { watershed }\end{array}$ & \multirow[t]{2}{*}{$\begin{array}{l}\text { Haileslassie et } \\
\text { al. (2006) }\end{array}$} \\
\hline $\begin{array}{l}\text { Teff-system } \\
\text { cultivation }\end{array}$ & Irrigation & 102 & 3.4 & 5.78 & 30 & WB & $\begin{array}{l}\text { Vertisols, } \\
\text { Leptosols }\end{array}$ & $2320-2620$ & $1117 \mathrm{~mm}$ & $\begin{array}{l}\text { Humid } \\
\text { highland }\end{array}$ & Gare watershed & \\
\hline Cereal & Irrigation & 21.95 & 5.9 & 10.03 & \multirow{3}{*}{30} & \multirow[t]{3}{*}{$\mathrm{DC}$} & \multirow{3}{*}{$\begin{array}{l}\text { Arenosols, } \\
\text { Regosols }\end{array}$} & \multirow[t]{3}{*}{$1960-2000$} & \multirow{3}{*}{$\begin{array}{c}15^{\circ} \mathrm{C} \text { and } 30^{\circ} \mathrm{C} \text {, and } \\
558 \mathrm{~mm}\end{array}$} & \multirow[t]{3}{*}{ Sub-humid } & \multirow{3}{*}{$\begin{array}{l}\text { Mandae } \\
\text { watershed }\end{array}$} & \multirow{3}{*}{$\begin{array}{l}\text { Mulualem et al. } \\
\text { (2015) }\end{array}$} \\
\hline Cereal & Rain-fed & 29.4 & 3.3 & 5.61 & & & & & & & & \\
\hline Agroforestry & Rain-fed & 36.6 & 6.4 & 10.9 & & & & & & & & \\
\hline Cereal & Rain-fed & 36.5 & - & - & \multirow[t]{2}{*}{50} & \multirow[t]{2}{*}{ DC-IRS } & Phaeozems & - & - & Sub- humid & Dambidolo & \multirow{2}{*}{$\begin{array}{l}\text { Vågen et al. } \\
(2013)\end{array}$} \\
\hline Cereal & Rain-fed & 18.7 & - & - & & & Leptosols & - & - & Humid highland & Kutaber & \\
\hline Grazing land & Rain-fed & 40.4 & - & - & 20 & WB & $\begin{array}{l}\text { Leptosol, } \\
\text { Regosols }\end{array}$ & - & $11-17$ and $26-34^{\circ} \mathrm{C}$ & Semi-arid & $\begin{array}{l}\text { Three districts of } \\
\text { Tigray }\end{array}$ & $\begin{array}{l}\text { Mekuria et al. } \\
(2009)\end{array}$ \\
\hline
\end{tabular}

$* \mathrm{WB}=$ Walkley-Black method; $\mathrm{WO}=$ Wet Oxidation method; $\mathrm{MW}=$ Modeling and wet method; $\mathrm{DC}=$ Dry combustion; DCA $=$ Dry combustion by Allison method; DC-LC-2000A = Dry combustion with LECO CNS-2000analyzer; Dry combustion elemental analyzer; and DC-IRS + Dry combustion and IR spectroscopy. 